\title{
The Influence of Curing Temperature on Rheological Properties of Epoxy Adhesives
}

\section{Utjecaj temperature otvrdnjavanja na reološka svojstva epoksidnih ljepila}

\author{
Original scientific paper • Izvorni znanstveni rad \\ Received-prispjelo: 16. 12. 2010. \\ Accepted-prihvaćeno: 25. 2. 2011. \\ UDK: $630 * 824.321 ; 630 * 824.421 .2$ \\ doi:10.5552/drind.2011.1042
}

\begin{abstract}
The curing process of three different epoxy adhesives, which are appropriate for bonding wood with metal, was characterized on the basis of their rheology. The rheological measurements were carried out using a TA Instruments ARES G2 stress control rheometer. The influence of temperature on the curing process was examined at five different temperatures: 30, 40, 50, 60 and $80^{\circ} \mathrm{C}$. Curing was monitored by an oscillatory test by using geometry with disposable parallel plates. Gel time and vitrification time were determined. Significant differences in curing behaviour were observed among the studied adhesives. The results showed that increasing the curing temperature significantly accelerated the curing process of the epoxy adhesives. It was also observed that the storage modulus $G$ ' and the loss modulus $G$ " decreased with an increasing temperature of curing.
\end{abstract}

Key words: epoxy adhesives, gel point, loss modulus, rheology, storage modulus

SAŽETAK • Proces otvrdnjavanja triju različitih epoksidnih ljepila koja se upotrebljavaju za povezivanje drva $i$ metala procijenjen je na bazi njihovih reoloških svojstava. Reološka su mjerenja provedena upotrebom reometra ARES G2. Utjecaj temperature na proces otvrdnjavanja istražen je pri pet različitih temperatura: 30, 40, 50, 60 i $80{ }^{\circ}$ C. Otvrdnjavanje je praćeno oscilacijskim testom primjenom geometrije sa slobodnim paralelnim pločama. Određeno je vrijeme geliranja i staklenosti. Utvrđeno je signifikantno različito ponašanje promatranih ljepila tijekom otvrdnjavanja. Rezultati su pokazali da se s povećanjem temperature otvrdnjavanja znatno ubrzava process otvrdnjavanja epoksidnih ljepila. Zapaženo je da se modul pohrane G'i modul gubitka G” smanjuju s povećanjem temperature otvrdnjavanja.

Ključne riječi: epoksidna ljepila, točka geliranja, modul gubitka, reologija, modul pohrane

\section{INTRODUCTION 1. UVOD}

Epoxy resins are often used as high performance thermosetting adhesives for bonding metals together or for binding metals to other materials. These adhesives are frequently used for bonding steel and wood, as for example in the case of structural connections in timber
(Broughton and Hutchinson, 2001; Custodio et al, 2009; Chans et al, 2010; Widman et al, 2007; Serrano, 2001; Cimadevila et al, 2007). Over the last 30 years, there has been a growing interest in the possibilities for jointing glulam beams with steel bars (rods), which are placed in pre-drilled holes in the timber members and bonded with epoxy resin. Such joints made with gluedin rods have great potential in the field of timber engi-

\footnotetext{
Authors are graduate student and associate professor at Biotechnical Faculty, University of Ljubljana, Ljubljana, Slovenia.

${ }^{1}$ Autori su student diplomskog studija i profesor na Biotehničkom fakultetu Sveučilišta u Ljubljani, Ljubljana, Slovenija.
} 
neering. Some of their advantages are the aesthetic benefits, with the hidden design of these rigid joints, and their high load-carrying capacity for the transmission of loads from and to the wooden pieces (Chans et al, 2009). Glued-in rods are very efficient joints, which can withstand the high axial loads that are applied to timber structural members. If such joints are correctly designed it is theoretically possible to achieve higher stiffness and a more uniform stress distribution in the wood, while avoiding peak values near the bolts and achieving a better aesthetic appearance in comparison with traditional mechanical connections (Gattesco and Gubana, 2001).

An important condition for the use of glued-in rods is that an efficient bond be created between the steel rods and timber. Gluing and screwing are two ways in which this can be done. Rod diameters larger than $10 \mathrm{~mm}$ make it impossible to achieve an efficient working screw system (Bernasconi, 2001). The load transfer between the screw and timber is mainly governed by compression due to indentation. Compared to screws, glued-in rods introduce shear forces into the timber in a different way. Whereas anchored screws rely on direct contact between the timber and the flanks of the thread, and therefore on compression by means of complex geometry, glued-in rods transfer the force only at the interface between the rod and the adhesive. The load transfer between the adhesive and timber is mainly governed by shear and not by compression due to indentation (Steiger et al, 2006). Due to this fact, gluing is the only way in which the bond can be created. Several parameters have an influence on the shortterm pull-out strength of glued-in rod joints. One of the very important mechanical parameters is the type and rheological behaviour of the adhesive (Rossignon and Espion, 2008). The purpose of the adhesive is to provide a continuous bond between the timber and steel rod, to fill voids and cavities, and to transfer and sustain the loads. Thus thermosetting gap-filling materials are required, which exhibit good adhesion to the various materials whilst also being tolerant to variations in the timber moisture content. Epoxy compounds have several advantages over other resins as adhesive agents for use in timber structures and, typically, they are suitable for service temperatures in the range -30 to $+60^{\circ} \mathrm{C}$. They may be formulated in a wide range of forms, application characteristics and mechanical properties when cured (Broughton and Hutchinson, 2001).

Before investigating the ability of different adhesives to promote adhesion in different types of joints, a detailed description of the rheological properties of each individual adhesive is needed (Lapique and Redford, 2002). Rheological information can be related directly to the mechanical properties of the adhesive (Zheng, 2002). Rheometry can be used not only to obtain information about gelation, but also to monitor the whole curing process of a thermoset (Núñez et al, 2005; Winter, 2008). The purpose of this study was to investigate the curing process and explore the rheology of three different epoxy adhesives, cured at several different temperatures.

\section{MATERIALS AND METHODS}

\section{MATERIJALI I METODE}

\subsection{Materials and sample preparation}

\subsection{Materijali i priprema uzoraka}

Three different epoxy adhesives were used. Adhesive ERGO 7211 2K EPOXY 50ml (7211) was a two-component epoxy resin with component A (colourless) and B (yellow). Its viscosity at $23{ }^{\circ} \mathrm{C}$ was 30000-45000 $\mathrm{mPa} \cdot \mathrm{s}$, whereas its acceptable thermal range was from $-40{ }^{\circ} \mathrm{C}$ to $+100{ }^{\circ} \mathrm{C}$, and its pot life at 23 ${ }^{\circ} \mathrm{C}$ was $100 \mathrm{~min}$. This resin contained N'-(3-aminopropyl)-N,N-dimethylpropane-1,3-diamine. The reaction product was bisphenol-A-(epichlorhydrin) epoxy resin (with a number-average molecular weight of 700) and bisphenol-F-(epiclorhydrin). Both components were mixed in advance. The recommended mixture ratio was $1: 1$.

The second adhesive was EPOX $210 \mathrm{~A}+\mathrm{B}$ (EPOX 210), which was a two-component-epoxy resin with component A (colourless) and B (yellow). The viscosity of component $\mathrm{A}$ at $25{ }^{\circ} \mathrm{C}$ was $500-900 \mathrm{mPa} \cdot \mathrm{s}$, whereas that of component B was $250 \mathrm{mPa} \cdot \mathrm{s}$. The viscosity of the mixture after $5 \mathrm{~min}$ was $600 \mathrm{mPa} \cdot \mathrm{s}$. Pot life at $20{ }^{\circ} \mathrm{C}$ was $30 \mathrm{~min}$ for $100 \mathrm{~g}$ and $11 \mathrm{~min}$ for 200 g. Component A contains 3-aminomethyl-3,5,5-threemetyl-cyclohexylamine, Benzyl alcohol, m-ksililendiamin, and Nonylphenol. Component B contains an epoxy resin, C 12-C14-Alkylglycidether. Both components were mixed in advance. The recommended mixture ratio was $\mathrm{A}: \mathrm{B}=2: 1$.

The third adhesive was NEOSTIK EP 101 (EP 101), which was a two-component modified epoxy resin with component $\mathrm{A}$ (colourless) and $\mathrm{B}$ (yellowbrown). Viscosity at $20^{\circ} \mathrm{C}$ for component A was 600 $\mathrm{mPa} \cdot \mathrm{s}$. Component A contains 4,4'-(1-methylethyliden e)bisphenol polymer with 2-(chloromethyl)oxirane with an average molecular weight $\leq 700 \mathrm{~g} / \mathrm{mol}$ and 2[(2-methylphenoxy)methyl]oxirane. Component B contains $N, N^{\prime}$-bis(2-aminoethyl)-1,2-ethanediamine. The recommended mixture ratio was $1: 1$.

\subsection{Rheological measurements}

2.2. Reološka mjerenja

The rheological measurements were carried out using a TA Instruments ARES G2 stress control rheometer. A diagram of the equipment for rheological measurements is shown in Figure 1. The geometry was plateplate, with disposable plates with a diameter of $25 \mathrm{~mm}$ made from steel with a nominal ultimate tensile strength of: $f_{\mathrm{u}}=900-1000 \mathrm{~N} / \mathrm{mm}^{2}$. All experiments were performed at a frequency of $1 \mathrm{~Hz}$, a strain of 0.01 , and a 0.5 mm gap between the plates. Sinusoidal stress was used in all experiments, which is the basis for calculating the storage modulus $\left(G^{\prime}\right)$ and the loss modulus $\left(G^{\prime \prime}\right)$.

All of the adhesives were used as received and carefully mixed at the stoichiometric ratio prescribed by the manufacturer. After preparing the adhesive sample, it was immediately placed in the plate-plate geometry assembly, and quickly heated $\left(60^{\circ} \mathrm{C} / \mathrm{min}\right)$ to the target curing temperature. Measurements always began 


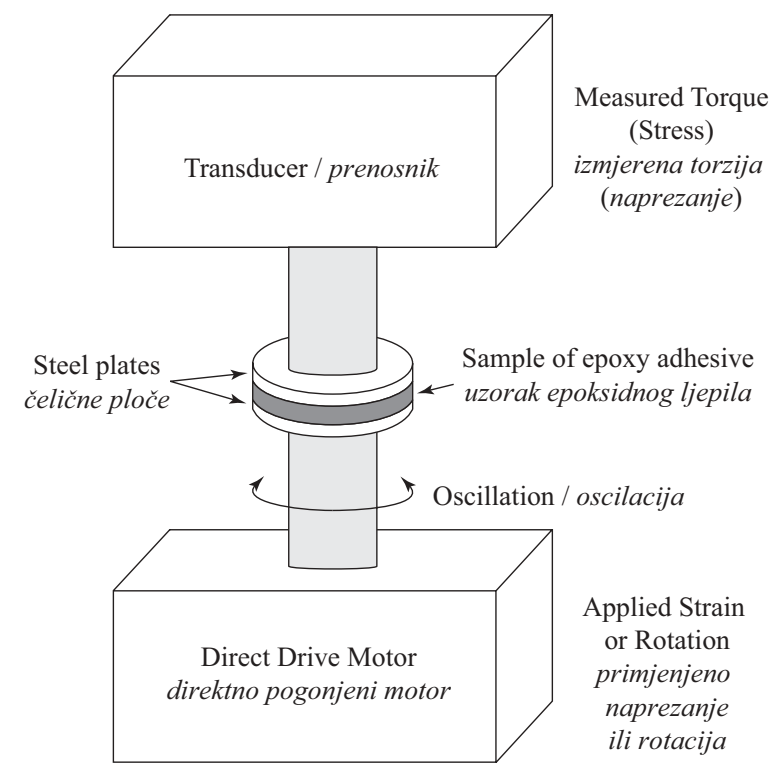

Figure 1 Diagram of the equipment for rheological measurements

Slika 1. Prikaz opreme za reološka mjerenja

immediately after achieving the target temperature. Five curing temperatures were used for each individual adhesive: $30,40,50,60$ and $80{ }^{\circ} \mathrm{C}$. Additionally, cooling from $80^{\circ} \mathrm{C}$ to $30^{\circ} \mathrm{C}$ was used in order to determine the cooling effect on the rheological properties of the cured EPOX 210 epoxy resins.

During the measurements, a control program was used to compensate for the thermal expansion of the test specimen dimensional changes during curing by maintaining a controlled normal force, which enabled the characterization of the cure over the whole conversion range. All the test specimens were prepared in the laboratory at $20{ }^{\circ} \mathrm{C}$ and at a relative humidity of $65 \%$.

\section{RESULTS AND DISCUSSION \\ 3. REZULTATI I RASPRAVA}

\subsection{Rheological analysis}

\subsection{Reološka analiza}

The rheological analysis used during the oscillatory test provided a total curing profile for the studied epoxy adhesives. Information about the curing behaviour of the adhesives was gained in terms of the measured storage modulus $G^{\prime}$ and the loss modulus $G^{\prime \prime}$. The curing profiles of the investigated epoxy adhesives at room temperature $\left(30^{\circ} \mathrm{C}\right)$ are shown in Figure 2. It can be observed, in the case of all the studied adhesives, that at the start of the curing, $G$ ” is greater than $G$ ' because the systems show a liquid type of behaviour. Then, both $G$ ' and $G$ "' increase as the cross-linking reaction progresses to a crossover point; here the systems present both elastic and viscous behaviour, storing a similar amount of the dissipated energy. In this zone gelation occurs. Later, the curing reaction progresses, and $G$ ' approached its maximum values whereas $G$ ", reached a peak and then started to decrease. In this zone vitrification occurred.

Gelation and vitrification of the adhesive can be detected through changes in the dynamical mechanical properties. Several different criteria can be used to define the gelation and vitrification times. The most generally accepted criterion for gelation is the crossover point of the shear storage modulus and loss modulus. However some authors consider that, in the case of many systems, the gel point is not necessarily equal to the calculated value at $G^{\prime}=G$ " (Winter, 1987; Núñez et al, 2005). Another criterion is that gelation occurs when viscosity increases exponentially to infinity. The problem is that infinity viscosity is very difficult to detect. One of the methods to identify the gel point is the criterion of the tangent line to the $G$ ' curve; the gel time is detected by the crossover between the tangent line at $G$ ' when this curve reaches a value close to 100 $\mathrm{kPa} \cdot \mathrm{s}$ and a baseline $G^{\prime}=0$ (Laza et al, 1998).

There is no generally accepted criterion for the detection of vitrification. In the case of the investigated epoxy resins, it was found that rheological vitrification is a gradual process that extends over a wide temperature range, depending on the criterion used. Vitrification can be determined from: the maximum $\tan \delta$ peak at $1 \mathrm{~Hz}$, the maximum $G^{\prime \prime}$ peak at $1 \mathrm{~Hz}$, the onset of frequency dependence in $G^{\prime}$, and with the end of frequency dependence in $G^{\prime}$ (Zheng, 2002). In this study, gel time $\left(t_{\text {gel }}\right)$ was taken as the time corresponding to the crossover of $G^{\prime} / G^{\prime}$. . Vitrification time $\left(t_{\mathrm{vit}}\right)$ was determined as the time corresponding to the time at which $G$ " has a peak at $1 \mathrm{~Hz}$. According to the so determined gel time and the vitrification time for curing adhesives at room temperature, the epoxy system 7211 cured fastest $\left(t_{\text {gel }}=238 \mathrm{~min}, t_{\mathrm{vit}}=297 \mathrm{~min}\right)$, followed by EPOX $210\left(t_{\mathrm{gel}}^{\mathrm{gel}}=345 \mathrm{~min}, t_{\mathrm{vit}}=527 \mathrm{~min}\right)$, and EP 101 $\left(t_{\mathrm{gel}}=499 \mathrm{~min}, t_{\mathrm{vit}}=565 \mathrm{~min}\right)$.

\subsection{The effect of temperature on curing profile of} adhesives

3.2. Utjecaj temperature na profile otvrdnjavanja ljepila

In order to characterize the influence of temperature on the curing process (i.e. on the storage and loss moduli, respectively), four additional higher temperatures (as well as $30^{\circ} \mathrm{C}$ ) were used for curing: 40, 50, 60 , and $80^{\circ} \mathrm{C}$. It was observed (Fig. 3) that increasing the temperature accelerated the curing reaction of the epoxy adhesive 7211 , but dramatically diminished the maximum values of $G$ ' and $G$ ". Also, time for transitions (i.e. gelation and vitrification) decreased with the increasing curing temperature. This was expected because the reaction of the adhesives was thermally accelerated. Similar behaviour was observed in the case of the other two adhesives (Fig. 4 and Fig. 5), but at different time periods.

The gel times and vitrification times for all three epoxy adhesives (Table 1), studied at different temperatures, were determined according to the above described criteria. It can be seen that gel time shortened with higher temperatures. This can be explained by the fact that when the temperature increases molecular mobility also increases, so the curing reaction occurs more rapidly. The vitrification times also shortened with higher temperatures, with some exceptions (EP 101 and EPOX 210 at 60 and $80^{\circ} \mathrm{C}$ ). 


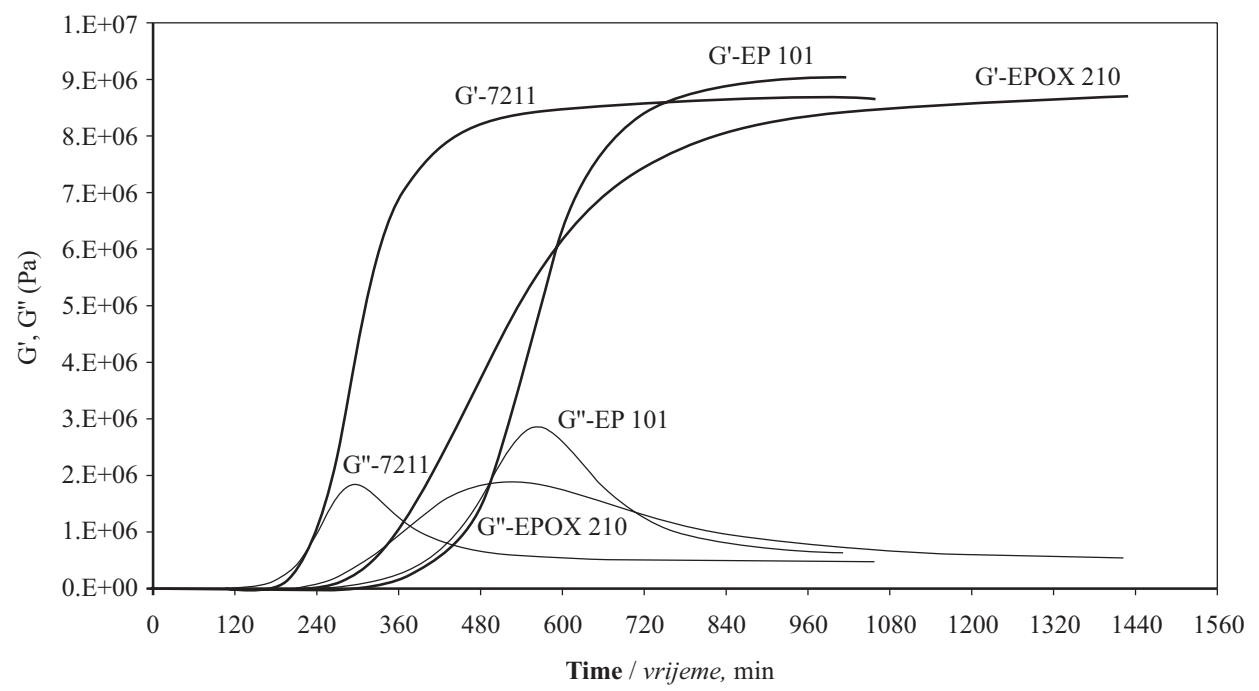

Figure 2 Curing profiles of epoxy adhesives at temperature of $30^{\circ} \mathrm{C}$

Slika 2. Profili otvrdnjavanja epoksidnih ljepila pri temperaturi $30^{\circ} \mathrm{C}$

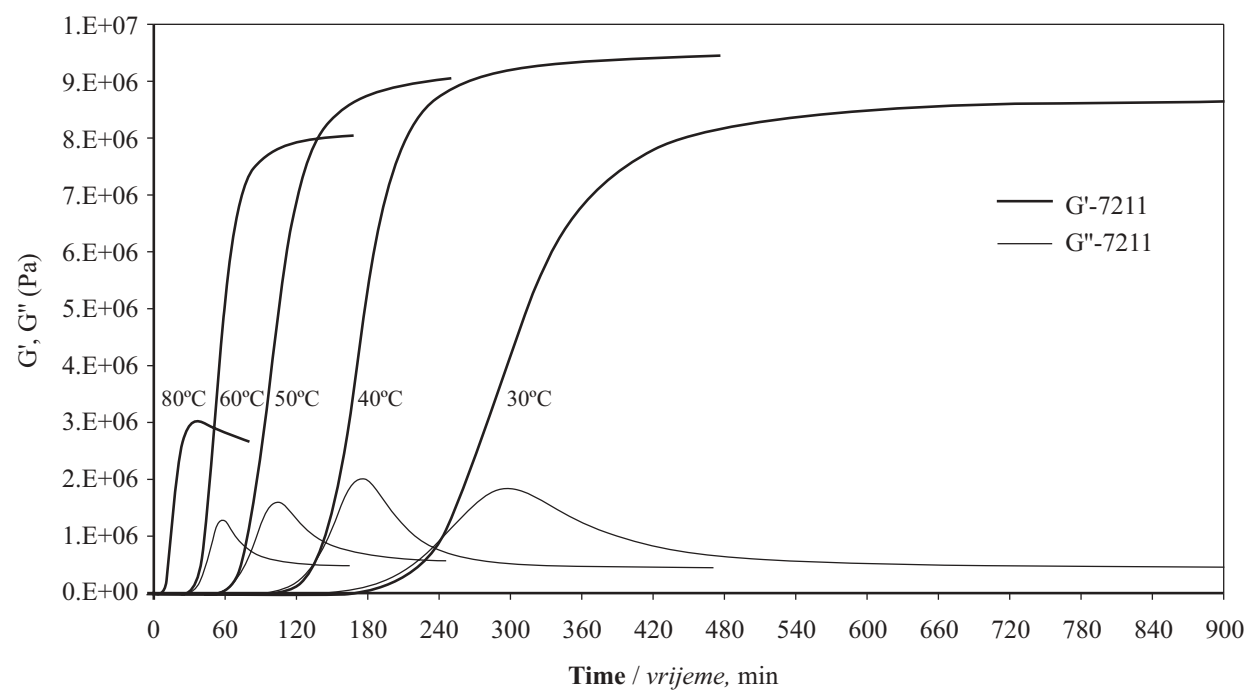

Figure 3 Plots of $G^{\prime}$ and $G$ " against time for the adhesive 7211, corresponding to the isothermal cure, at different curing temperatures

Slika 3. Krivulje ovisnosti modula $G$ ' i $G$ ” o vremenu za ljepilo 7211 dobivene praćenjem krivulja izotermnog otvrdnjavanja pri različitim temperaturama otvrdnjavanja

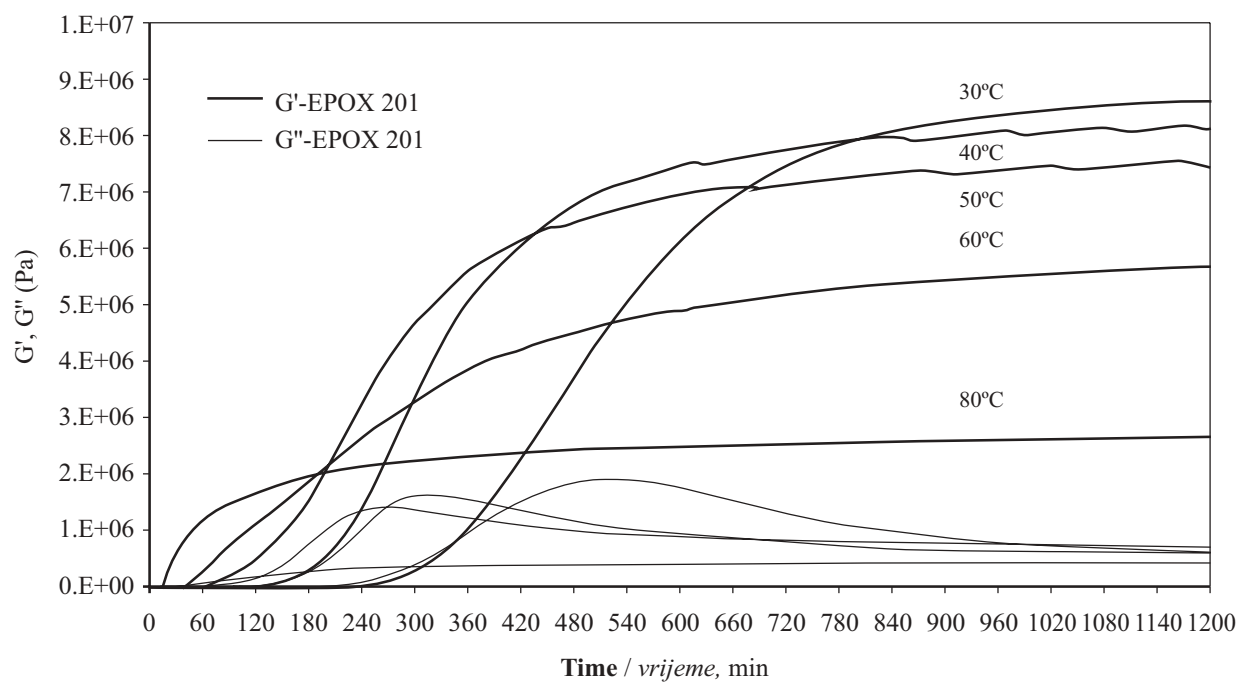

Figure 4 Plots of $G$ ' and $G$ ", against time for the adhesive EPOX 201, corresponding to the isothermal cure, at different curing temperatures

Slika 4. Krivulje ovisnosti modula $G$ ' i $G$ " o vremenu za ljepilo EPOX 201 dobivene praćenjem krivulja izotermnog otvrdnjavanja pri različitim temperaturama otvrdnjavanja 


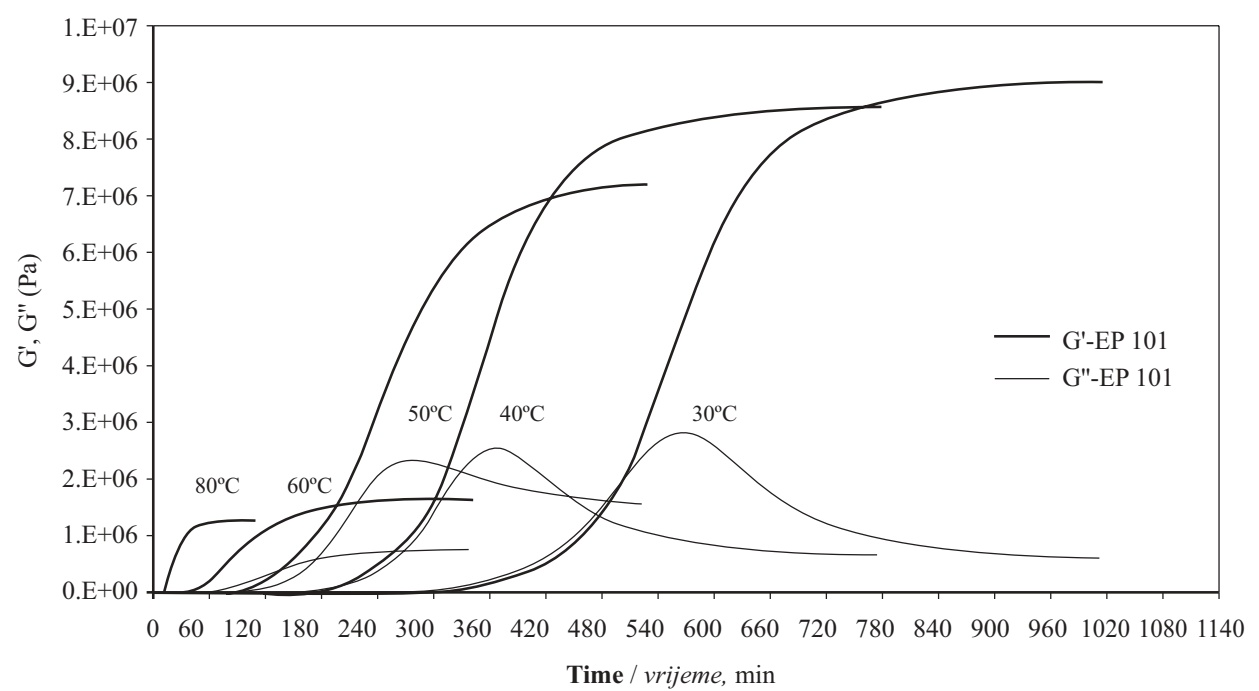

Figure 5 Plots of $G$ ' and $G$ "' against time for the adhesive EP 101, corresponding to the isothermal cure, at different curing temperatures

Slika 5. Krivulje ovisnosti modula $G$ ' i $G$ ”' o vremenu za ljepilo EP 101 dobivene praćenjem krivulja izotermnog otvrdnjavanja pri različitim temperaturama otvrdnjavanja

The influence of temperature on the curing process can be explained by the nature of epoxy adhesives. The epoxy adhesive, as a thermoset polymer, is a material whose properties are dependent not only on the test environment but also on its thermal and environmental history. A thermoset adhesive has a glass transition temperature $\left(T_{\mathrm{g}}\right)$ (Lapique and Redford, 2002). Glass transition is a phase change of amorphous solids, such as glasses and polymers. A non-crystalline material is converted to a relatively hard, elastic and glassy state from a soft, elastic-plastic and rubbery state when cooled through its $T_{\mathrm{g}}(\mathrm{Li}, 2000) . T_{\mathrm{g}}$ is influenced by different factors such as composition of the resin molecule, crosslink density, the polar nature of the functional groups of resin molecules, the curing agent or catalyst, curing time and curing temperature (Tamulewich and Moore, 1980). Basically polymers with longer molecular chains, more hydrogen bonds, polar or polarizable groups and crosslinking networks tend to have a higher $T_{\mathrm{g}}$. On the other hand materials with symmetric (non-polarized) molecular structures or with a plasticizer (softener) tend to have a lower $T_{\mathrm{g}}(\mathrm{Li}, 2000)$.

The glass transition temperature is a direct measurement of molecular mobility. Below $T_{\mathrm{g}}$, a molecule is confined to its site, with a very limited group of branch movement freedom, and its free volume is relatively small. Whole molecules cannot move away from each other. Above $T_{\mathrm{g}}$, a molecule has much more freedom of movement, and its free volume increases faster with the temperature. Whole molecules can shift or slide away from each other (Li, 2000).

Other mechanical properties vary in accordance with these changes in the degree of cure and plastification. The temperature at which they are cured determines many of the properties of epoxy adhesives. $T_{\mathrm{g}}$ can be a measure of the degree of cure of an epoxy resin system. Therefore the cure time and temperature can have a very dramatic effect upon the $T_{\mathrm{g}}$ of any given epoxy system. At temperatures close to $T_{\mathrm{g}}$, the values of the mechanical properties such as tensile strength, lap shear and adhesive bond shear and modulus are substantially reduced. This can be seen in Fig. 4; where the values of both moduli $(G$, $G$ ') diminish at higher temperatures. Above a temperature level of $\sim 50{ }^{\circ} \mathrm{C}$ both moduli were drastically reduced, because the cure temperature was near the glass transition temperature. At higher temperatures the curing times were diminished, too. At $30^{\circ} \mathrm{C}$ the maximum value of $G$ 'was reached after $\sim 1000$ min, whereas at $80{ }^{\circ} \mathrm{C}$ it was reached after only $\sim 60 \mathrm{~min}$, which is almost $17 \times$ less than at $30^{\circ} \mathrm{C}$.

\subsection{The effect of temperature on G' and G" values of the cured adhesive}

3.3. Utjecaj temperature na vrijednosti G' i G" stvrdnutog ljepila

The effect of temperature on the $G$ ' and $G$ " values corresponding to a cured adhesive was studied in detail with the EPOX 201 adhesive (Fig. 6). Measurements began after the target curing temperature $\left(80^{\circ} \mathrm{C}\right)$

Table $1 \mathrm{Gel}\left(t_{\mathrm{gel}}\right)$ and vitrification $\left(t_{\mathrm{vit}}\right)$ times for the studied epoxy adhesives

Tablica 1. Vrijeme geliranja $\left(t_{\text {gel }}\right)$ i staklenosti $\left(t_{\text {vit }}\right)$ za promatrana ljepila

\begin{tabular}{|c|c|c|c|c|c|c|}
\hline $\begin{array}{c}\text { Adhesive } \\
\text { Ljepilo }\end{array}$ & \multicolumn{2}{|c|}{ EP 101 } & \multicolumn{2}{c|}{ EPOX 210 } & \multicolumn{2}{c|}{} \\
\hline$T,{ }^{\circ} \mathrm{C}$ & $t_{\mathrm{gel}}, \min$ & $t_{\mathrm{vit}}, \min$ & $t_{\mathrm{gel}}, \min$ & $t_{\mathrm{vit}}, \min$ & $t_{\mathrm{gel}}, \min$ & $t_{\mathrm{vit}}, \min$ \\
\hline $\mathbf{3 0}$ & 499 & 565 & 345 & 527 & 238 & 297 \\
\hline $\mathbf{4 0}$ & 186 & 365 & 151 & 321 & 139 & 174 \\
\hline $\mathbf{5 0}$ & 91 & 277 & 69 & 272 & 64 & 103 \\
\hline $\mathbf{6 0}$ & 44 & 334 & 38 & 457 & 30 & 57 \\
\hline $\mathbf{8 0}$ & 8 & 103 & 11 & 1183 & 6 & 33 \\
\hline
\end{tabular}




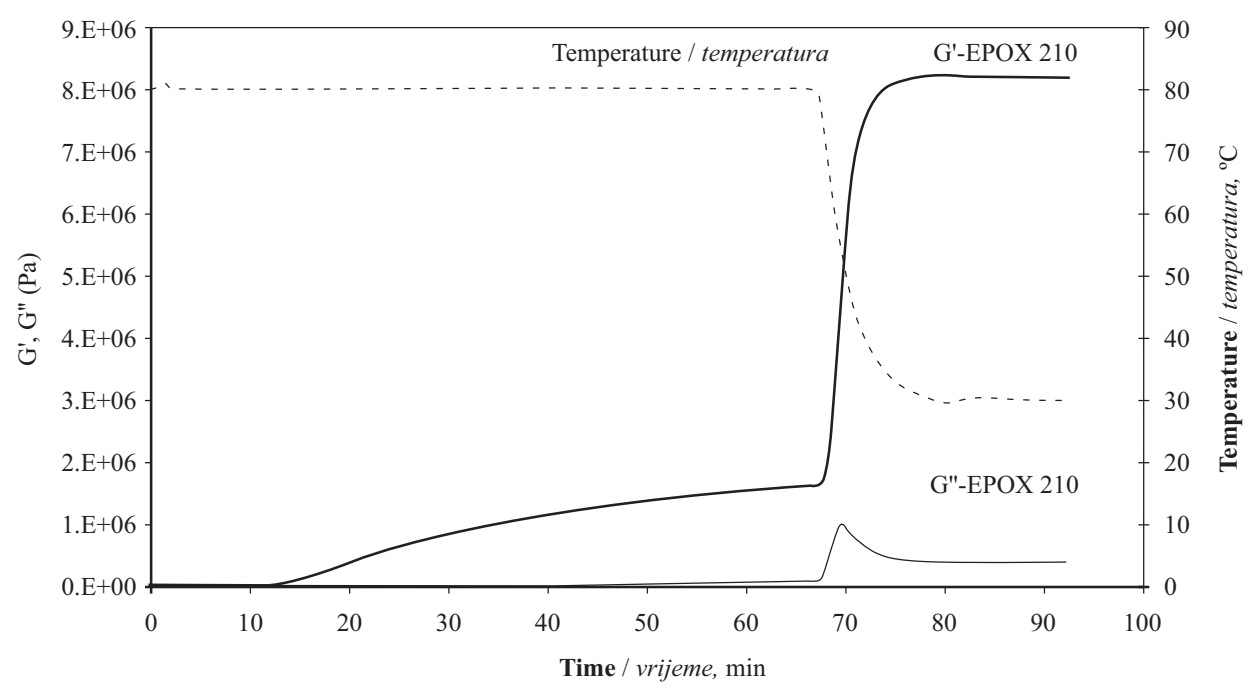

Figure 6 The influence of heating and immediate cooling on $G$ ' and $G$ " values of the EPOX 210 adhesive Slika 6. Utjecaj grijanja i trenutačnog hlađenja na vrijednosti $G$ ' i $G$ ” ljepila EPOX 210

had been reached. When the maximum value of $G^{\prime}$ had been reached, the heating stopped. Cooling was then started from $80^{\circ} \mathrm{C}$ to $30^{\circ} \mathrm{C}$ with a temperature ramp of $30{ }^{\circ} \mathrm{C} / \mathrm{min}$. It can be seen that, after cooling, $G^{\prime}$ increased to a value that is practically the same as if the curing process had occurred at $30{ }^{\circ} \mathrm{C}$. As mentioned above, the reason for such behaviour lies in the glass transition temperature. In the first part of the experiment, the curing temperature was near $T_{\mathrm{g}}$; which explains why both moduli were so low. After cooling, both moduli became increasingly higher.

\section{CONCLUSIONS}

4. ZAKLJUČCI

The rheological properties of three different epoxy adhesives were investigated at five curing temperatures. Gelation and vitrification were detected through changes in the dynamic mechanical properties for each individual adhesive. According to the determined gel times and vitrification times for the curing of the adhesives at room temperature, the epoxy system 7211 cured fastest $\left(t_{\mathrm{gel}}=238 \mathrm{~min}, t_{\mathrm{vit}}=297 \mathrm{~min}\right)$, followed by EPOX 210 $\left(t_{\mathrm{gel}}=345 \mathrm{~min}, t_{\mathrm{vit}}=527 \mathrm{~min}\right)$ and EP $101\left(t_{\mathrm{gel}}=499 \mathrm{~min}\right.$, $\left.t_{\text {vit }}=565 \mathrm{~min}\right)$. The results showed that the curing temperature had a significant influence on the rheology of the investigated epoxy adhesives. It was observed that increased temperatures accelerated the curing reaction of all of the studied epoxy adhesives, but dramatically diminished the maximum achieved values of $G$ ' and $G$ ". The time for the transitions such as gelation and vitrification decreased with increased curing temperatures. The effect of temperature on the $G$ ' and $G$ "' values of the cured adhesive was clear: cooling of the cured adhesive from $80{ }^{\circ} \mathrm{C}$ to $30^{\circ} \mathrm{C}$ increased the $G$ ' and $G$ " values several times, which was associated with the glass transition behaviour of the adhesive.

\section{Acknowledgements - Zahvala}

The authors gratefully acknowledge the financial support of the Slovenian Research Agency within the framework of the research program P4-0015-0481.

\section{REFERENCES}

5. LITERATURA

1. Bernasconi, A., 2001: Axially loaded glued-in rods for high capacity joints - behaviour and resistance. In: Proceedings of the International RILEM - Symposium on Joints in Timber Structures. Stuttgart, pp. 373-381.

2. Broughton, J.G.; Hutchinson, A.R., 2001: Adhesive systems for structural connections in timber. Int. J. Adhes. Adhes. 2: 177-186 doi:10.1016/S0143-7496(00)00049-X

3. Calabrese, L.; Valenza, A., 2003: Effect of CTBN rubber inclusions on the curing kinetic of DGEBA-DGEBF epoxy resin. Eur. Polym. J. 39: 1355-1363. doi:10.1016/S0014-3057(02)00390-7

4. Chans, O.M.D.; Cimadevila, E.J.; Gutiérrez, M.E.; Rodríguez, V.J.A., 2010: Influence of timber density on the axial strength of joints made with glued-in steel rods: An experimental approach. Int. J. Adhes. Adhes. 30: 380385. doi:10.1016/j.ijadhadh.2010.03.004

5. Cimadevila, E.J.; Rodríguez, V.J.A.; Chans, O.M.D., 2007: Experimental behaviour of threaded steel rods glued into high - density hardwood. Int. J. Adhes. Adhes. 27: 136-144. doi:10.1016/j.ijadhadh.2006.01.006

6. Custódio, J.; Broughton, J.; Cruz, H., 2009: A review of factors influencing the durability of structural bonded timber joints. Int. J. Adhes. Adhes. 29: 173-185. doi:10.1016/j.ijadhadh.2008.03.002

7. Gattesco, N.; Gubana, A., 2001: Experimental tests on glued joints under axial forces and bending moments. In: Proceedings of the International RILEM - Symposium on Joints in Timber Structures. Stuttgart, pp. 353-362.

8. Harper, D.P.; Wolcott, M.P.; Rials, T.G., 2001: Evaluation of the cure kinetics of the wood/pMDI bond line. Int. J. Adhes. Adhes. 21: 137-144. doi:10.1016/S0143-7496(00)00045-2

9. Lapique, F.; Redford, K., 2002: Curing effects on viscosity and mechanical properties of a commercial epoxy resin adhesive. Int. J. Adhes. Adhes. 22: 337-346. doi:10.1016/S0143-7496(02)00013-1

10. Laza, J.M.; Julian, C.A.; Larrauri, E.; Rodriguez, M.; Leon, L.M., 1998: Thermal scanning rheometer analysis of curing kinetic of an epoxy resin: 2 . An amine as curing agent. Polym. 40: 35-45.

doi:10.1016/S0032-3861(98)00217-1 
11. Li, R., 2000: Time-temperature superposition method for glass transition temperature of plastic materials. Mater. Sci. Eng. A278: 36-45. doi:10.1016/S0921-5093(99)00602-4

12. Montserrat, S.; Roman, F.; Colomer, P., 2003: Vitrification and dielectric relaxation during the isothermal curing of an epoxy - amine resin. Polym. 44: 101-114. doi:10.1016/S0032-3861(02)00745-0

13. Núñez, L.; Gómez-Barreiro, S.; Gracia-Fernández, C.A., 2005: Study of the influence of isomerism on the curing properties of the epoxy system DGEBA(n=0)/1,2-DCH by rheology. Rheol. Acta. 45: 184-191.

14. Rossignon, A.; Espion, B., 2008: Experimental assessment of the pull-out strength of single rods bonded in glulam parallel to the grain. Holz als Roh- und Werkstoff.

15. Sernek, M.; Kamke, F.A., 2007: Application of dielectric analyses for monitoring the cure process of phenol formaldehyde adhesive. Int. J. Adhes. Adhes. 27: 562-567. doi:10.1016/j.ijadhadh.2006.10.004

16. Serrano, E., 2001: Glued-in rods for timber structures An experimental study of softening behaviour. Mater. Struct. 34: 228-234. doi:10.1007/BF02480593

17. Steiger, R.; Gehri, E.; Widmann, R., 2006: Pull-out strength of axially loaded steel rods in glulam parallel to the grain. Mater. Struct. 40: 69-78.

doi:10.1617/s11527-006-9111-2

18. Tamulevich, T.W.; Moore, V., 1980: The Significance of Glass Transition Temperature on Epoxy Resins for Fiber
Optic Applications. Epoxy Technology Inc. http://www. epotek.com/SSCDocs/whitepapers/Tech\%20Paper \%2011.pdf. Accessed 15 September 2010

19. Widman, R.; Steiger, R.; Gehri, E., 2007: Pull-out strength of axially loaded steel rods bonded in glulam perpendicular to the grain. Mater. Struct. 40: 827-838. doi:10.1617/s11527-006-9214-9

20. Zheng, J., 2002: Studies of PF resole / isocyanate hybrid adhesives. Dissertation, Virginia Polytechnic Institute and State University

21. Winter, H.H., 1987: Can the gel point of a cross-linking polymer be detected by the G' - G' crossover? Polym. Eng. Sci. 27: 1698-1702. doi:10.1002/pen.760272209

22. Winter, H.H., 2008: Physical and Chemical Gelation. Encyclopedia of Materials: Science and Technology, p.p. 6991-6999.

\section{Corresponding address:}

Associate Professor MILAN ŠERNEK, Ph.D.

University of Ljubljana, Biotechnical Faculty Department of Wood Science and Technology Rožna dolina, C. VIII/34

SI-1000 Ljubljana, Slovenia

e-mail: milan.sernek@bf.uni-lj.si 